\title{
European-wide opposition against the breast cancer gene patents
}

\author{
Gert Matthijs*,1 and Dicky Halley $^{2}$ \\ ${ }^{1}$ Center for Human Genetics, University of Leuven, Leuven, Belgium; ${ }^{2}$ Department of Clinical Genetics, Erasmus MC, \\ Rotterdam, The Netherlands
}

European Journal of Human Genetics (2002) 10, 783 - 784. doi:10.1038/sj.ejhg.5200924

In 2001, the European Patent Organisation (EPO) granted three patents on the BRCA1 gene, the first known gene with a role in familial breast- and ovary cancer, to Myriad Genetics, a US based company. Typically, patenting protects intellectual property (IP) and allows inventors an incentive in the form of a time-limited right to the economic exploitation of the invention. Society benefits from products arising from the invention and, generally, further development is facilitated by its early accessibility, through publication in the patent literature.

Through the BRCA1 patents, Myriad Genetics aims to obtain the monopoly on diagnostic testing for mutations in this gene. However, since 1994 many laboratories in Europe (and elsewhere) have been offering BRCA1 testing in a clinical context. As a result of the monopoly on this gene, this testing will either become impossible in the laboratories in the public sector, or become significantly more expensive.

The BRCA1 patents illustrate the risks of 'ownership' of a gene sequence and have evoked strong reactions in Europe. Most importantly, these gene patents may create a precedent. Hundreds of patent applications on genes have been filed over the last few years. If not stopped, monopolies on genes and genetic testing may wreck existing and wellfunctioning reimbursement systems and will negatively influence healthcare all over Europe.

The European Patent Convention (EPC) allows a democratic control on patenting via an opposition procedure.

\footnotetext{
${ }^{*}$ Correspondence: G Matthijs, Lab. Moleculaire Diagnose, Centrum voor Menselijke Erfelijkheid, Gasthuisberg, Herestraat 49, B-3000 Leuven, Belgium. Tel: +32 16 346070/345903; Fax: +32 16 346060;

E-mail: Gert.Matthijs@med.kuleuven.ac.be

Received 24 September 2002; revised 23 October 2002; accepted 23
} October 2002
In October 2001, a French association of research institutes and hospitals, and a coalition of the Belgian, Dutch, British, Danish and German genetic societies opposed the first patent (EP-B-699754). For the opposition against the second patent (EP-B-705903) in February 2002, the Belgian and Dutch governments joined the latter group. For the opposition against the third patent (EP-B-705902) in August 2002, the original 'Belgian-Dutch' initiative was further extended, and included molecular and clinical geneticists, oncologists and cancer researchers from Austria, Belgium, Czech Republic, Denmark, Finland, Germany, Greece, Italy, the Netherlands, Switzerland and the United Kingdom. Two Dutch and Belgian patient organisations have also joined the opposition.

For a patent to be granted, the claimed invention must be (1) novel and (2) non-obvious, ie 'inventive' and (3) have an industrial application. In our view, the BRCA1 patents lack novelty and 'inventive step'.

In 1990, Mary Claire King and her co-workers located the BRCA1 gene to chromosome $17 \mathrm{q} 21 .{ }^{1}$ From then on, several groups have offered predictive testing for familial breast cancer on the basis of linkage analysis. Thus, a method for diagnosing a predisposition to breast cancer was available prior to the priority date of the patents (August 12, 1994). While the availability of mutation analysis was an asset, like the Nuffield Council on Bioethics, ${ }^{2}$ we argue that establishing the relationship between mutations and a disease constitutes a discovery rather than an invention.

The opposing parties further argue that there is a lack of 'inventive step' because the patentees have benefited in a major way from prior research through an international consortium on BRCA with the indispensable collaboration of patients and families. Evidently, the identification of 
BRCA1 was a laborious and costly effort. However, neither this nor the reduction of the time to reach an obvious goal, involves 'inventive step' in the sense of patent law.

Also, in Article 52(4) the EPC excludes diagnostic methods practised on the human body from patenting; we argue that mutation analysis of a disease-related gene using a blood sample constitutes a medical act within the meaning of this article. Even if the sample is literally divorced from the body, the link to the person is not lost.

Moreover, the specific nature of DNA as a carrier of genetic and private information requires special considerations. Actual patent law and the evidently narrow and strict interpretation by the EPO do not sufficiently reflect this special status. When the uniqueness of the genetic code is combined with the exclusive rights of patents, a truly unbreakable monopolistic right is generated.

Such a monopoly will hamper progress. The patent system protects and rewards the inventor, but is also meant to create an incentive for others to try and 'invent around', and thus to promote progress. The latter is not possible when the sequence itself is the subject of the claims. We call upon those private companies that have a prime interest in the development of novel technologies for genetic analysis, to join us in our action.

Finally, we call upon EPO to revise the current interpretation of the regulations to award gene sequence patents and urge patent owners to reconsider their approach to exploiting gene sequence IP. We call upon legislators, companies and the public for awareness of the issues around patenting DNA sequences.

\section{References}

1 Hall JM, Lee MK, Newman B, Morrow JE, Anderson LA, Huey B, King MC: Linkage of early-onset familial breast cancer to chromosome 17q21. Science 1990; 250: 1684-1689.

2 Nuffield Council on Bioethics. The ethics of patenting DNA (Available via http//www.nuffieldbioethics.org/publications/ pp_0000000014.asp and launched on July 23, 2002). 